\title{
Competence and longevity in planulae of several species of soft corals
}

\author{
R. Ben-David-Zaslow*, Y. Benayahu \\ Department of Zoology, George S. Wise Faculty of Life Sciences, Tel Aviv University, Tel Aviv 69978, Israel
}

\begin{abstract}
Longevity and competence were studied in planulae of several species of Red Sea soft corals, including the zooxanthellate planulae of Litophyton arboreum, Nephthea sp. and Xenia umbellata, and the azooxanthellate planulae of Parerythropodium fulvum fulvum and Dendronephthya hemprichi. The relationship between presence of zooxanthellae in the planulae and their competence, longevity and caloric content was examined. Planulae of $X$. umbellata and $D$. hemprichi had the longest competency of 76 and $74 \mathrm{~d}$, respectively, planulae of $P$. f. fulvum were competent for a maximal period of $64 \mathrm{~d}$, and planulae of $L$. arboreum and Nephthea sp. showed a similar competency of $57 \mathrm{~d}$. The highest longevity of $155 \mathrm{~d}$ was found in planulae of $X$. umbellata. Planulae of P. f. fulvum, D. hemprichi and $L$. arboreum had maximum longevities of 76, 81 and $92 \mathrm{~d}$, respectively. No significant differences existed between the competence or longevity of the zooxanthellate and azooxanthellate planulae. The ratio of the maximum values of longevity to competency was significantly higher for the zooxanthellate compared to the azooxanthellate planulae. That zooxanthellate planulae survived beyond their competence period might be due to the ability of larvae to utilize photosynthates produced by the zooxanthellae. However, the presence of symbiotic algae in planulae does not necessarily increase competency. The caloric value of $3 \mathrm{~d}$ old planulae of $P$. f f fulvum was $0.096 \pm 0.002 \mathrm{cal}^{\text {planula }}{ }^{-1}$, and that of $4 \mathrm{~d}$ old planulae of $X$. umbellata was $0.012 \pm 0.001 \mathrm{cal}$ planula ${ }^{-1}$. The caloric content of the former decreased with development, but increased in the latter. These results support the assumption that the photosynthates of symbiotic algae contribute to the energetic content of the planulae throughout their life. Considering the competence and longevity of the planulae, it is concluded that they are able to disperse from the southern Red Sea reefs to the degraded reefs of Eilat (northern Red Sea).
\end{abstract}

KEY WORDS: Planulae $\cdot$ Longevity $\cdot$ Caloric content $\cdot$ Competence $\cdot$ Octocorallia $\cdot$ Red Sea

\section{INTRODUCTION}

The Octocorallia constitute a group of moderate diversity with approximately 2000 species (Bayer 1973). They can be found from shallow water extending down to the ocean depths. Octocorals of the order Alcyonacea are common throughout the Indo-Pacific region, and hundreds of different species inhabit a range of reef habitats along a wide depth gradient. The early studies of Gohar $(1940 a, b)$ on the biology of species of the family Xeniidae in the Red Sea were followed by additional ecological studies on alcyonaceans (e.g. Fishelson 1970, 1973a, Schuhmacher 1975 , Benayahu \& Loya 1977, 1981, 1987, Benayahu 1985)

•E-mail: revitbd@ccsg.tau.ac.il which revealed that alcyonacean soft corals form a major benthic component on the Red Sea reefs and are widely distributed among various habitats.

For many years, sexual reproduction in octocorals was best known for the temperate alcyonacean species Alcyonium digitatum (Hartnoll 1975). The last 2 decades, however, have seen an increase in knowledge of the sexual reproduction of Indo-Pacific alcyonaceans (e.g. Aliño \& Coll 1989, Benayahu et al. 1990, Benayahu 1991, 1997). The findings emphasize the plasticity of the reproductive characteristics of this group. Three modes of reproduction have been described for reef alcyonaceans: internal brooding, external surface brooding of planulae and broadcast spawning (Benayahu et al. 1990). Planulation is featured by various species of the family Xeniidae (Gohar 1940a, b, Benayahu 1991) as well as by zooxanthellate species of 
the family Nephtheidae (Benayahu et al. 1992, Benayahu 1997); external surface brooding occurs in several species representing various families (Benayahu et al. 1990, Coma et al. 1995); and broadcast spawning was recorded in the family Alcyoniidae (Babcock et al. 1986. Aliño \& Coll 1989, Benayahu et al. 1990), as well as in the azooxanthellate Dendronephthya species of the family Nephtheidae (Benayahu 1997). Some of the zooxanthellate alcyonaceans produce zooxanthellate planulae, such as Xenia macrospiculata (Benayahu \& Loya 1984), X. umbellata (Benayahu et al. 1988), Litophyton arboreum (Benayahu et al. 1992) and Nephthea sp. (Benayahu 1997). Others have azooxanthellate planulae, e.g. Parerythropodium fulvum fulvum (Benayahu \& Loya 1983), Sarcophyton glaucum (Benayahu \& Loya 1986), Clavularia hamra (Benayahu 1989) and Heteroxenia fuscescens (Benayahu et al. 1989a, b). All of these species acquire their zooxanthellae at a primary polyp stage (Benayahu et al. 1989a).

For larvae of marine invertebrates, competence is operationally defined as the ability to metamorphose following exposure of the larvae to a demonstrated natural inducer. This definition, while functionally and ecologically appropriate, does not account for the factors and steps which may intervene between initial induction of settlement behavior and subsequent metamorphosis (Coon et al. 1990). Larvae become competent to metamorphose at a certain stage of their development which may occur either before their release into the water or, alternatively, after a certain period of planktonic existence (Harrison \& Wallace 1990, Pechenik 1990). The ability to postpone metamorphosis in the absence of suitable conditions may allow larvae to find habitats most likely to support their future survival and successful reproduction (Crisp 1974, Paige 1988, Pechenik 1990, Pechenik \& Cerulli 1991, Walters 1992). Both metamorphosis and competence have been shown to relate to the energetic content of the larvae (Lucas et al. 1979, Richmond 1987, 1989, Jaeckle \& Manahan 1989, 1992, Pechenik 1990, Qian et al. 1990. Harms 1992, Havenhand 1993, Jaeckle 1994). Richmond $(1987,1989)$ found a competence period of $100 \mathrm{~d}$ for the zooxanthellate planulae of the stony coral Pocillopora damicornis and a shorter period of $21 \mathrm{~d}$ for the azooxanthellate planulae of Acropora tenuis. Translocated metabolites from the symbiotic algae have been suggested to extend the competence period, which in turn increases the dispersal period of the planulae (Richmond 1989). Among soft corals a competency period of at least $60 \mathrm{~d}$ was found for the azooxanthellate planulae of Dendronephthya hemprichi (Dahan 1992) and of $49 \mathrm{~d}$ for the azooxanthellate planulae of Heteroxenia fuscescens (Ben-David-Zaslow \& Benayahu 1996).
We studied the longevity and competency of planulae of several Red Sea soft corals, including zooxanthellate species with zooxanthellate planulae, Litophyton arboreum, Nephthea sp. (family Nephtheidae) and Xenia umbellata (family Xeniidae), a zooxanthellate species with azooxanthellate planulae, Parerythropodium fulvum fulvum (family Alcyoniidae), and the azooxanthellate Dendronephthya hemprichi (family Nephtheidae). We attempted to assess the relationships between the caloric value of planulae, the presence of zooxanthellae in planulae, and the longevity and competency of planulae.

\section{MATERIALS AND METHODS}

Collection of corals and planulae. The studied species were collected from the coral reef in front of the Marine Biology Laboratory (MBL) at Eilat (Red Sea) during April 1992 to November 1993. After collection, ca 25 colonies of Xenia umbellata and 8 to 10 branches (10 to $15 \mathrm{~cm}$ in length) of Litophyton arboreum, Nephthea sp. and Dendronephthya hemprichi were placed in 151 containers supplied with running seawater, at a flow rate of $21 \mathrm{~min}^{-1}$. Before sunset the colonies or branches were transferred into aerated $5 \mathrm{l}$ aquaria in the laboratory and examined the following morning for the presence of released planulae or eggs. Spawned eggs and sperm of $D$. hemprichi were mixed in 51 aquaria and the resulting embryos were reared to the planulae stage in aerated 51 aquaria (Dahan 1992). Planulae of the surface brooder Parerythropodium fulvum fulvum were removed from female colonies during their breeding season (Benayahu \& Loya 1983). Planulae obtained from all the 5 species studied were placed in $500 \mathrm{ml}$ PVC containers, filled with Milliporefiltered $(0.45 \mu \mathrm{m})$ seawater (FSW), containing Ampi-

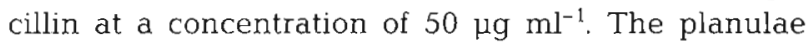
( 1 to $2 \mathrm{~d}$ old) were transported to Tel-Aviv, Israel, for further experiments, all conducted in natural Red Sea water in a controlled temperature room, corresponding to the ambient seasonal Red Sea temperature (21 to $\left.26^{\circ} \mathrm{C}\right)$. The light regime followed day/night cycles $(400$ to $700 \mathrm{~nm}$ ). The availability of planulae throughout the study period dictated the number of planulae tested and number of replications (see below).

Natural settlement of planulae. Determination of the precompetent period of the planulae preceded the competence experiments. For this purpose in July, August and September 1992 batches of fresh planulae of the 5 studied species were placed in aquaria at the $\mathrm{MBL}$, each with $5 \mathrm{l}$ of sea water $\left(26^{\circ} \mathrm{C}\right)$ with natural reef substrata (fragments of dead Stylophora pistillata colonies freshly collected from the reef). The experiments were carried out with the following total numbers of planulae 
for all the replications: Parerythropodium fulvum fulvum $500(\mathrm{n}=3)$, Dendronephthya hemprichi $200(\mathrm{n}=1)$, Litophyton arboreum $180(\mathrm{n}=2)$, Nephthea sp. $326(\mathrm{n}=4)$, and Xenia umbellata $795(\mathrm{n}=2)$. Settlement and metamorphic events of these planulae were monitored every 2 to $4 \mathrm{~h}$ during the first 2 to $3 \mathrm{~d}$, and then every 3 to $5 \mathrm{~d}$ for a total period of 17 to $20 \mathrm{~d}$. Planulae were considered to initiate metamorphosis only after they had settled and developed a mouth and tentacular buds.

Competence of the planulae. In Tel Aviv the 1 to $2 \mathrm{~d}$ old planulae of all studied species were washed 3 times with FSW to remove organic debris before being placed in batches of up to 250 planulae in Erlenmeyer flasks containing $300 \mathrm{ml} \mathrm{FSW}$ with Ampicillin $(50 \mu \mathrm{g}$ $\mathrm{ml}^{-1}$ ). Ampicillin in FSW enabled survival of the planulae for the longest possible period, preventing settlement and metamorphosis due to possible induction by bacteria (Ben-David-Zaslow \& Benayahu 1996). Planulae samples were taken from the above-mentioned batches at 3 to $5 \mathrm{~d}$ intervals, and the Ampicillin treatment was terminated by washing them 3 times with FSW to remove residual antibiotics. They were then placed in 24-well tissue-culture plates in groups of 10 planulae, with each well containing $2.5 \mathrm{ml} \mathrm{FSW}$. The number of planulae that underwent metamorphosis in each time interval was recorded, thus enabling determination of competency. The longest competence period recorded for planulae of each species was defined as the maximal competency. The experiments were run for each of the studied species on different dates during their respective breeding seasons. For the number of planulae used on each date see 'Results'.

Longevity of the planulae. Longevity of planulae was examined for all species except Nephthea sp. Planulae were maintained similarly to the procedure described above for the competence experiments. They were transferred to new flasks with fresh FSW containing Ampicillin every 2 to $3 \mathrm{~d}$, and the number of planulae surviving was measured every $5 \mathrm{~d}$, thus enabling determination of longevity. For the number of planulae used on each date see 'Results'.

Calorimetric analysis. The determination of caloric content as a function of age was performed for the azooxanthellate planulae of Parerythropodium fulvum fulvum and the zooxanthellate Xenia umbellata. We analyzed 2 batches of $X$. umbellata, each with 250 planulae, at ages $4,11,35,55$ and $66 \mathrm{~d}$ and 2 batches of $P$. f. fulvum, each with 300 planulae, at ages $2,4,11$ and $24 \mathrm{~d}$ as dictated by availability of planulae. Calorimetry was performed with a Phillipson Microbomb Calorimeter. Calibration curves were calculated using benzoic acid samples (Scott \& Marlow 1982). Because ash level was less than $2 \%$ dry weight, dry weight was considered equivalent to ash-free dry weight for the planulae.

\section{RESULTS}

\section{Natural settlement of planulae}

Onset of metamorphosis was observed in 1 to $2 \mathrm{~d}$ old planulae of Parerythropodium fulvum fulvum (Fig. 1a) that gradually developed into primary polyps (Fig. 1b). Similarly, planulae of Litophyton arboreum (Fig. 1c) and Nephthea sp. (Fig. 1d) metamorphosed at 1 to $2 \mathrm{~d}$ of age. The planulae of Dendronephthya hemprichi (Fig. 1e) and Xenia umbellata (Fig. 1f) started to metamorphose after 2 to $3 \mathrm{~d}$. After 17 to $20 \mathrm{~d}$ the following average percentages of metamorphosed planulae were recorded: $P$. f. fulvum $57.6 \pm 2.9(\mathrm{n}=3)$, D. hemprichi 59 $(\mathrm{n}=1), L$. arboreum $53.7 \pm 9.6(\mathrm{n}=2)$. Nephthea $\mathrm{sp}$. $81.5 \pm 7.7(\mathrm{n}=4)$, and $X$. umbellata $53.3 \pm 4.5(\mathrm{n}=2)$.

\section{Competence of the planulae}

Competence of the studied planulae to metamorphose was calculated on each date from the percentage undergoing metamorphosis with time (Fig. 2). The inhibitory effect of the Ampicillin caused a time lag and hence metamorphosis began in the different species 5 to $20 \mathrm{~d}$ after termination of the antibiotic treatment. Planulae of Xenia umbellata and Dendronephthya hemprichi had the longest competence periods, 76 and 74 d, respectively (Fig. 2). Planulae of Parerythropodium fulvum fulvum were competent for $64 \mathrm{~d}$, and planulae of Litophyton arboreum and Nephthea sp. showed a similar maximal competence period of $57 \mathrm{~d}$. There was no significant difference between the maximal competence of the zooxanthellate and azooxanthellate planulae ( $t$-test, $p>0.05)$. In these experiments the average maximal percentage of metamorphosed planulae varied among species and ranged between a lowest value of $37 \pm 14$ in $X$. umbellata and a highest value of $86 \pm 3$ in P. f. fulvum (Fig. 2).

\section{Longevity of the planulae}

The survivorship curves for the various batches of planulae are shown in Fig. 3. Planulae of Xenia umbellata had the highest longevity of $155 \mathrm{~d}$ and survived even when they became morphologically abnormal, demonstrating irregular shapes, blisters and other abnormalities (Fig. 1g). Abnormalities occurred in all planulae batches of $X$. umbellata after around $75 \mathrm{~d}$. The other examined species, Parerythropodium fulvum fulvum, Dendronephthya hemprichi and Litophyton arboreum, had maximal longevity periods of 76, 81 and $92 \mathrm{~d}$ respectively (Fig. 3). There was no significant difference between the average survivorship 


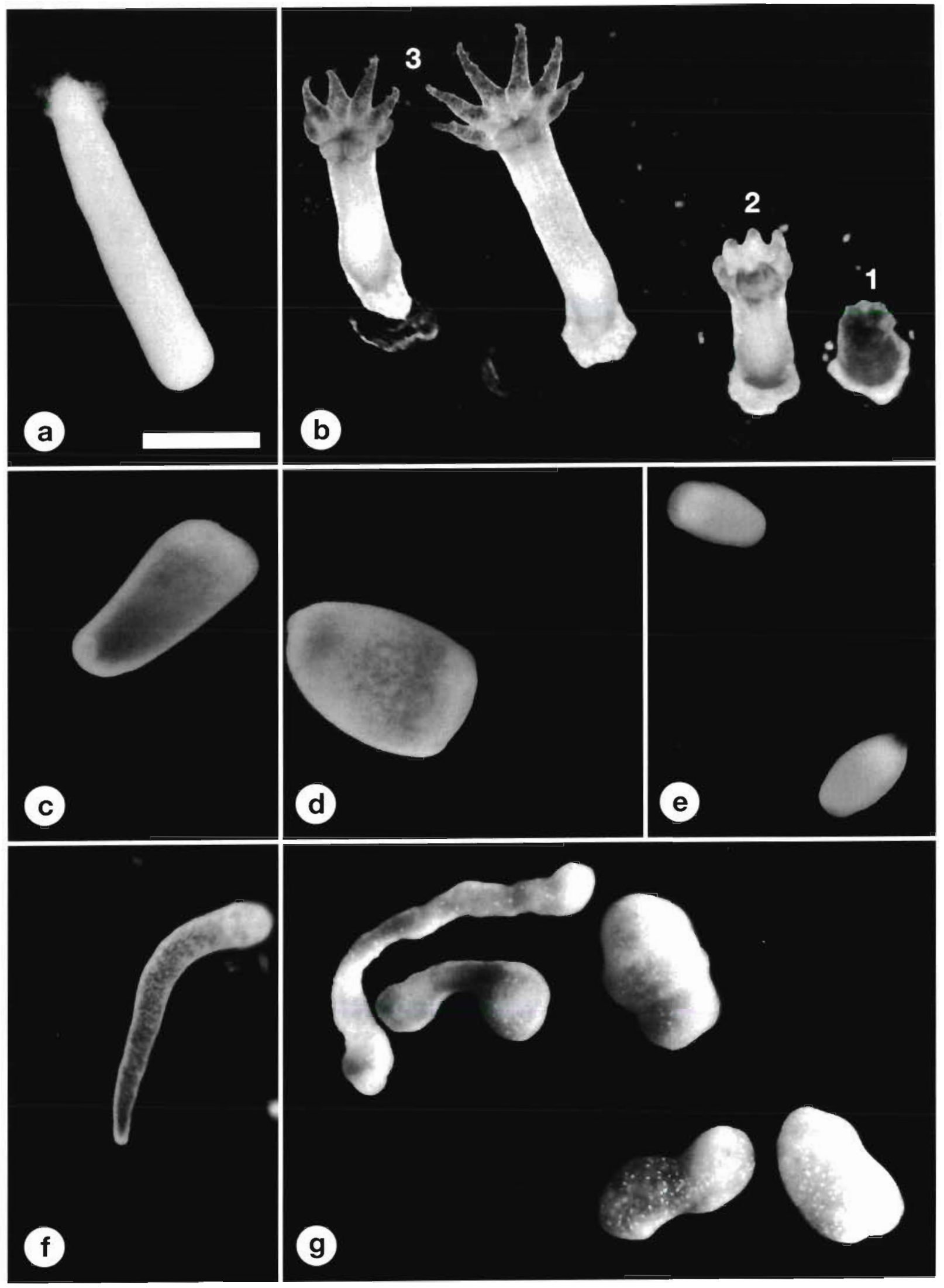


Fig. 1. (a) 1 to 2 d old planula of Parerythropodium fulvum fulvum; (b) different metamorphic stages of primary polyps of $P$. f. fulvum: (1) $2 \mathrm{~d}$ old. (2) $1 \mathrm{wk}$ old, (3) 2 mo old; (c) 1 to 2 a planula of Litophyton arboreum; (d) planula of Nephthea sp.; (e) 1 to $2 \mathrm{~d}$ planulae of Dendronephthya hemprichi; (f) 1 to 2 d planula of Xenia umbellata; (g) $145 \mathrm{~d}$ old planulae of $X$. umbellata with morphological abnormalities

values of the zooxanthellate and azooxanthellate planulae $(t$-test, $p>0.05)$. In these experiments, time to $50 \%$ mortality of the different planulae ranged between $11 \mathrm{~d}$ (P. f. fulvum, 15 Jul 1992 experiment) and 72 d (X. umbellata, 30 Sep 1992 experiment) (Fig. 3).
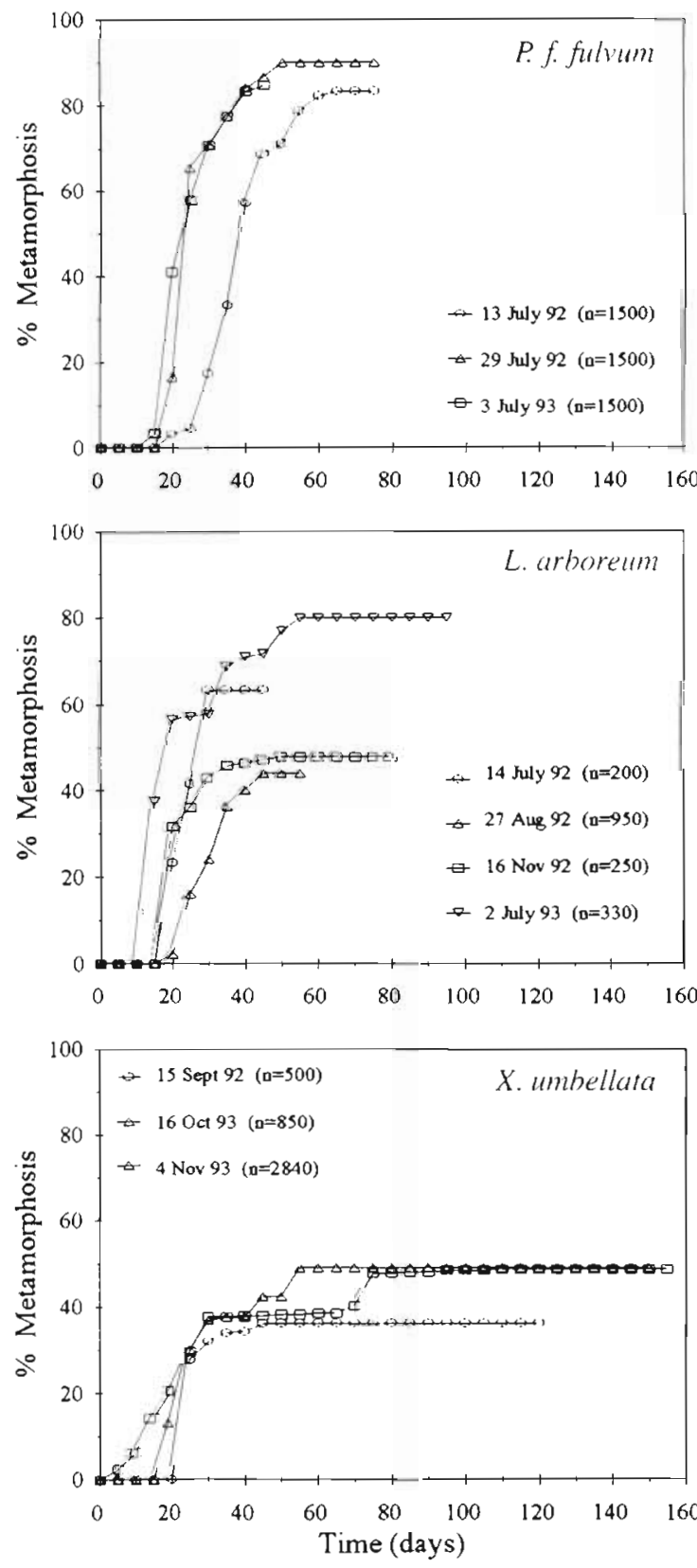

\section{Calorimetric analysis}

The caloric value of $3 \mathrm{~d}$ old planulae of Parerythropodium fulvum fulvum was $0.096 \pm 0.002 \mathrm{cal}^{\text {planula }}{ }^{-1}$ ( $\mathrm{n}=2,250$ planulae per replication) and for $4 \mathrm{~d}$ old
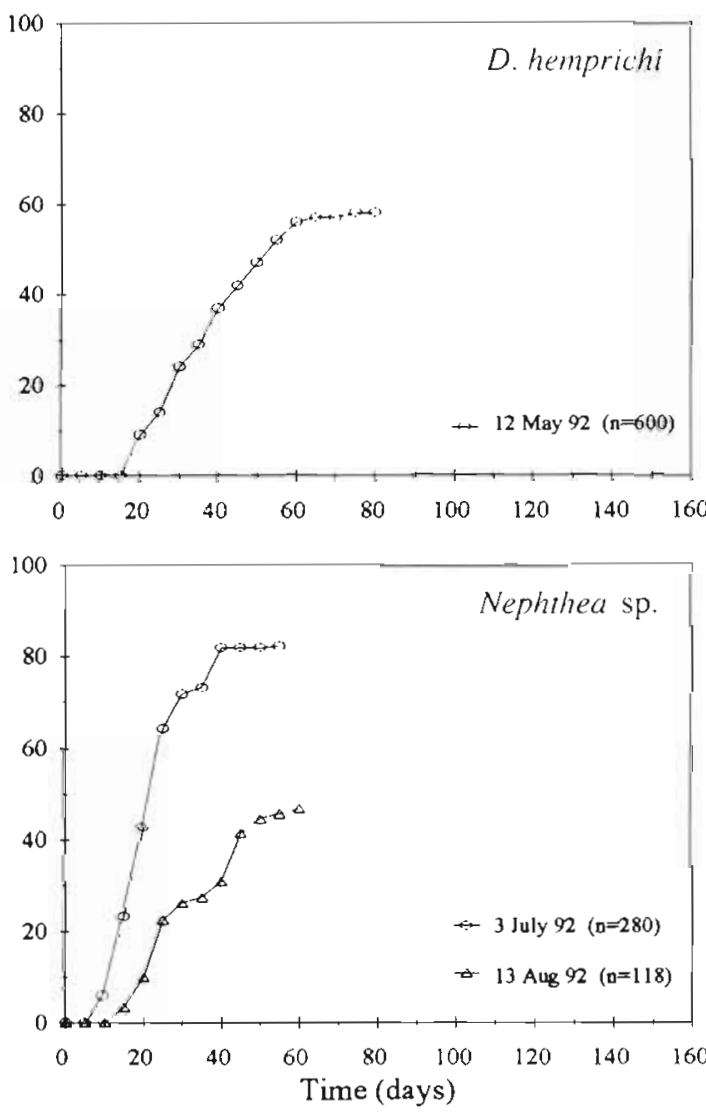

Fig. 2. Percentage of surviving planulae of soft corals undergoing metamorphosis over time. Starting date and sample size are given for each experiment 

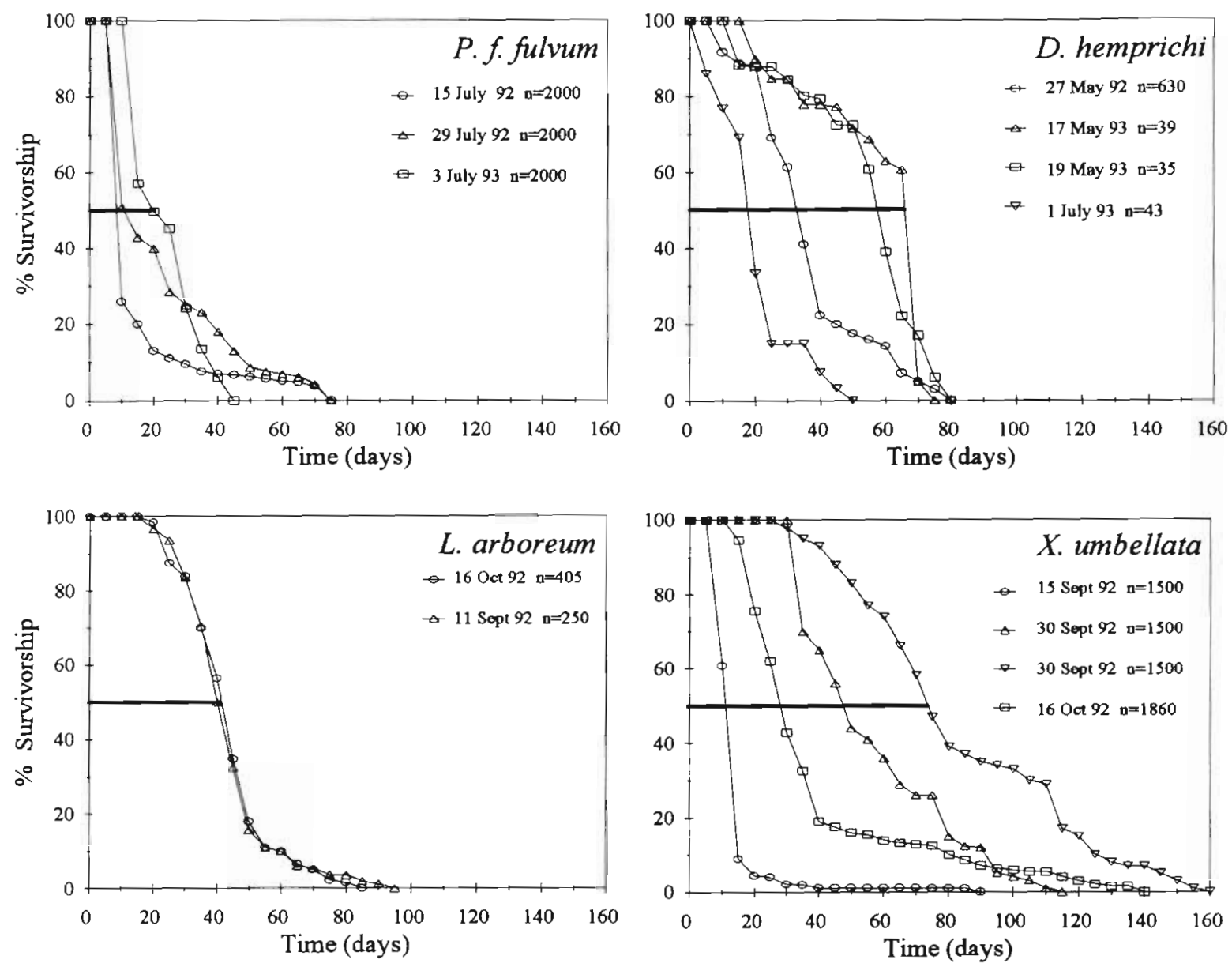

Fig. 3. Survivorship curves of planulae of soft corals at different times. Horizontal line in each graph corresponds to $50 \%$ survivorship. Starting date and sample size are given for each experiment

planulae of Xenia umbellata it was $0.012 \pm 0.001 \mathrm{cal}$ planula $^{-1}$ ( $n=2,300$ planulae per replication). The caloric content of $X$. umbellata planulae increased 6 -fold to a maximum of $0.072 \pm 0.001 \mathrm{cal}^{\mathrm{c}} \mathrm{planula}^{-1}$ on Day 35 of their life, however in P. f, fulvum it decreased to a minimum of $0.049 \pm 0.001 \mathrm{cal} \mathrm{planula}^{-1}$ on Day 24 . The caloric contents of $X$. umbellata planulae decreased after Day 35 (Fig. 4).

\section{DISCUSSION}

The onset of metamorphosis did not occur immediately upon release, but began 1 to $3 \mathrm{~d}$ later in all the studied species. These results correspond to previous findings on planulae of other alcyonaceans (Sebens 1983, Farrant 1986, Aliño \& Coll 1989, Lasker \& Kim 1996) and scleractinians (Harrison \& Wallace 1990), showing a precompetent period of a few days. Planulae of the soft coral Heteroxenia fuscescens, however, lack a pre-competent period (Ben-David-Zaslow \& Benayahu 1996) and thus differ from the others. The effective dispersal period for propagules depends on the time span that larvae require to become competent and on the time that passes before the competent larvae encounter the stimuli necessary to initiate their metamorphosis (Pechenik 1990). Hence, we propose that soft corals with longer pre-competent periods may

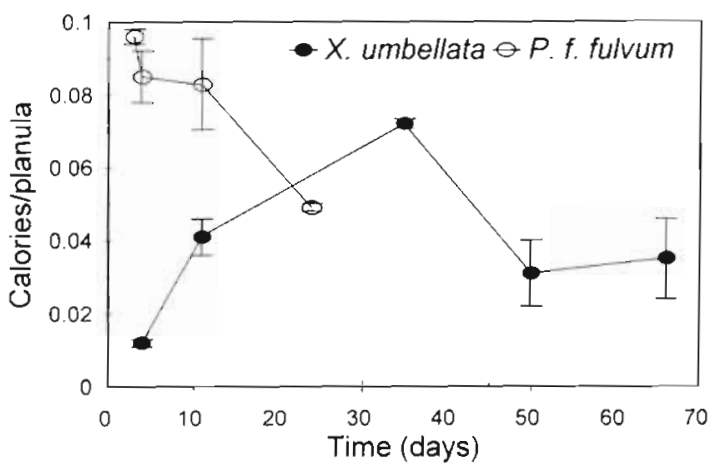

Fig. 4. Average caloric content ( $\mathrm{SD}$ ) of Parerythropodium fulvum fulvum and Xenia umbellata planulae measured during the study ( 2 replications for each age group) 
have a more effective dispersal capability from their parent colonies.

The current results indicate that there is no significant difference between the competence period of the zooxanthellate and azooxanthellate planulae. This differs from results obtained for scleractinian corals, which indicate higher competency for zooxanthellate planulae (Richmond 1987, 1989). Planulae with a longer competence period, such as Xenia umbellata (76 d) and Dendronephthya hemprichi (this study: 74 d: Dahan 1992: 60 d), have a greater potential for dispersal, in contrast to planulae with a short competence period such as Heteroxenia fuscescens (49 di Ben-David-Zaslow \& Benayahu 1996).

The maximum longevity and competence periods for planulae of the studied species (Figs. 2 \& 3) are presented in Table 1 along with those of Heteroxenia fuscescens (Ben-David-Zaslow \& Benayahu 1996). In order to quantify possible differences between zooxanthellate and azooxanthellate planulae we calculated the ratio of maximum survival to maximum competence for each species. The comparison between the 2 larval groups was found to be significant ( $t$-test, $\mathrm{p}<0.05$; Table 1). The azooxanthellate planulae survived for only a few days after their competency terminated and thus have a low ratio of longevity to competence. However, the zooxanthellate planulae survived longer and therefore show a greater value for this ratio, as demonstrated by Xenia umbellata whose planulae survived for the longest period of $155 \mathrm{~d}$, but which had a competence period of only $76 \mathrm{~d}$ (Figs. $2 \& 3$, Table 1).

It is well documented that in zooxanthellate anthozoans photosynthetically fixed carbon passes into the host tissue (e.g. Tytler \& Spencer-Davies 1986). This energy resource might also be available to the sexual progeny of a symbiotic host, as found for the veligers of the giant clam Tridacna gigas and the bivalve Hippopus hippopus. These larvae have a higher growth rate in the presence of zooxanthellae compared to larvae held in isolation with no symbionts (Fitt et al. 1986). Zooxanthellate planulae of scleractinian corals gain photosynthetic energy from their own symbionts (Richmond 1987, 1989). Thus, we suggest that the photosynthates available to zooxanthellate planulae enable them to survive beyond their competence period, even after they lose their normal morphology (Fig. 1g). However, our results indicate that the presence of symbiotic algae in the planulae does not necessarily increase their competency.

Since most of the studies on longevity and competence periods of marine larvae have been carried out in the laboratory (Pechenik 1990), the results may not reflect behavior in the natural environment. In projecting from estimates of dispersal capabilities, it is necessary to consider the behavior of the planulae. Jackson (1986) claimed that planulae of brooding scleractinian corals swim for much shorter periods than those of broadcasters. Many brooded planulae never swim but rather crawl on bottom reef-surfaces, and thus their dispersal is limited (Benayahu \& Loya 1983, Benayahu 1989, Harrison \& Wallace 1990). However, since in the present study all planulae were kept under identical experimental conditions, we presume that any variation in the competence and longevity among the species may also exist under the natural reef-environment conditions

Studies of competence and longevity of larvae in relation to their energetic content (Lucas et al. 1979, Richmond 1987, 1989, Jeackle \& Manahan 1989, 1992, Pechenik 1990, Qian et al. 1990, Harms 1992, Havenhand 1993, Jaeckle 1994, Pechenik et al. 1996) have emphasized the importance of stored energy for dispersal. There is a variability in orders of magnitude among the energetic content of freshly released planulae of Xenia umbellata: $0.012 \pm 0.001 \mathrm{cal}$ planula ${ }^{-1}, P_{a r}$ erythropodium fulvum fulvum: $0.096 \pm 0.002$ cal planula $^{-1}$ (this study) and Heteroxenia fuscescens: $0.58 \pm$ 0.05 cal planula $^{-1}$ (Ben-David-Zaslow \& Benayahu 1996). These caloric values indicate the lowest maternal energetic investment in zooxanthellate compared to azooxanthellate planulae. The caloric content of the zooxanthellate planulae of $X$. umbellata initially increased,

Table 1. Maximal longevity, maximal competence and the calculated ratio between these values for various zooxanthellate and azooxanthellate soft coral planulae

\begin{tabular}{|c|c|c|c|c|c|}
\hline Family & Species & $\begin{array}{l}\text { Presence of } \\
\text { zooxanthellae in } \\
\text { planulae stage }\end{array}$ & $\begin{array}{l}\text { Maximal } \\
\text { longevity } \\
\text { (d) }\end{array}$ & $\begin{array}{l}\text { Maximal } \\
\text { competence } \\
\text { (d) }\end{array}$ & $\begin{array}{l}\text { Longevity/ } \\
\text { competence } \\
\text { ratio }\end{array}$ \\
\hline Alcyoniidae & Parerythropodium f. fulvum & No & 76 & 64 & 1.18 \\
\hline \multirow{3}{*}{ Nephtheidae } & Dendronephthya hemprichi & No & 81 & 74 & 1.09 \\
\hline & Litophyton arboreum & Yes & 92 & 57 & 1.61 \\
\hline & Nephthea sp. & Yes & - & 57 & - \\
\hline \multirow[t]{2}{*}{ Xeniidae } & Xenia umbellata & Yes & 155 & 76 & 2.04 \\
\hline & Heteroxenia fuscescens ${ }^{a}$ & No & 50 & 49 & 1.02 \\
\hline
\end{tabular}


while in the azooxanthellate planulae of $P$. f. fulvum and $H$. fuscescens it steadily decreased with time (Fig. 4; Ben-David-Zaslow \& Benayahu 1996). The caloric content of $X$ umbellata planulae started to decrease from Day 35 of their release (Fig. 4), at the same time that most of the planulae stopped being competent to metamorphose (Fig. 2). Planulae of $H$. fuscescens have a short competency period ( $49 \mathrm{~d}$ ) compared to $X$. umbellata ( $76 \mathrm{~d}$ ) and P. f. fulvum (64 d) (Table 1). Our results lead us to suggest that the symbiotic algae may contribute significantly to the energetic content of the planulae in the course of the first period of their life, but do not necessarily increase their competency. In order to answer further questions related to the significance of temporal changes in the energetic content of planulae, and their relation to the dispersal capabilities of a given species, further physiological studies are required.

This study provides for the first time a comparative data set on longevity and competence in planulae of various soft corals, which determines the dispersal potential of the species. Due to anthropogenic disturbances at Eilat (e.g. oil and phosphate pollution and increased tourism activities) the reefs have become degraded (Fishelson 1973b, Loya 1975, 1986, Rinkevich \& Loya 1977, authors' pers. obs.) and rates of recruitment of both scleractinian and soft corals are low. Alcyonacean soft corals constitute a dominant group of organisms on the northern Red Sea reefs (Benayahu \& Loya 1977, 1981). Given the prevailing current regime in the Gulf of Eilat (A. Genin pers. comm.), larvae are advected from the southern Red Sea reefs to Eilat and other northern areas within a period of a few weeks. The results of the present study indicate that soft coral planulae derived from the reefs of the southern Red Sea will be competent on arrival at the Ellat reefs and may recruit there.

Acknowledgements. We express our gratitude to $M$. llan for his useful suggestions and criticism during the study. We are grateful to A. Ar and A. Belinsky for assistance in the calorimetric work. We acknowledge the insightful critiques of the manuscript by $C$. Johnson. The comments of the anonymous reviewers are gratefully acknowledged. We thank the staff of the Interuniversity Manine Institute of Biology at Eilat for their hospitality and facilities. A. Shoob is acknowledged for the photography and N. Paz for her editorial assistance. The research was supported in part by a grant from the Israeli Diving Federation. This paper constitutes part of a M.Sc. thesis submitted by R.B.-D.-Z.

\section{LITERATURE CITED}

Aliño PM, Coll JC (1989) Observations of the synchronized mass spawning and postsettlement activity of octocorals on the Great Barrier Reef, Australia: biological aspects. Bull Mar Sci 45:697-707
Babcock RC, Bull JD, Harrison PL, Heyward AJ, Olover JK, Wallace CC, Willis BL (1986) Synchronous spawning of 105 scleractinian coral species on the Great Barrier Reef. Mar Biol 90:379-394

Bayer FM (1973) Colonial organization in octocorals. In: Brodman RS, Cheetman $\mathrm{AH}$, Oliver WA (eds) Animal colonies development and function through time. Dowden, Hutchinson \& Ross, Inc, Stroudsburg, p 69-93

Benayahu Y (1985) Faunistic composition and patterns in the distribution of soft corals (Octocorallia, Alcyonacea) along the coral reefs of Sinai penninsula. Proc 5th Int Coral Reef Congr, Tahiti 6:255-260

Benayahu Y (1989) Reproductive cycle and developmental processes during embryogenesis of Clavularia hamara (Cnidaria: Octocorallia). Acta Zool (Stockh) 70:29-36

Benayahu Y (1991) Reproduction and developmental pathways of Red Sea Xeniidae (Octocorallia, Alcyonacea). Hydrobiologica 216/217:125-130

Benayahu Y (1997) Developmental episodes in reef soft corals: ecological and cellular determinants. Proc 8th Int Coral Reef Symp, Panama City 2:1213-1218

Benayahu Y, Achituv Y, Berner T (1988) Embryogenesis and acquisition of algal symbionts by planulae of Xenia umbellata (Octocorallia: Alcyonacea). Mar Biol 100:93-101

Benayahu Y, Achituv Y, Berner T (1989a) Metamorphosis of an octocoral primary polyp and its infection by algal symbiosis. Symbiosis 7:159-169

Benayahu Y, Berner T, Achituv Y (1989b) Development of planulae within a mesogleal coat in the soft coral Heteroxenia fuscescens. Mar Biol 100:203-210

Benayahu Y, Loya Y (1977) Space partitioning by stony corals, soft corals and bentic algae on the coral reefs of the northern Gulf of Eilat (Red Sea). Helgol Wiss Meeresunters 30:362-382

Benayahu Y, Loya Y (1981) Competition for space among coral reef sessile organisms at Eilat. Bull Mar Sci 31:514-522

Benayahu Y, Loya Y (1983) Surface brooding in the Red-Sea soft coral Parerythropodium f. fulvum. Biol Bull Mar Biol Lab Woods Hole 165:353-369

Benayahu Y, Loya Y (1984) Life history studies on Red Sea soft coral Xenia macrospiculata Gohar, 1940 II. Planulae shedding and post larval development. Biol Bull Mar Biol Lab Woods Hole 166:44-53

Benayahu Y, Loya $Y$ (1986) Sexual reproduction of a soft coral; synchronous and brief annual spawning of Sarcophyton glaucum. Biol Bull Mar Biol Lab Woods Hole 170: $32-42$

Benayahu Y, Loya Y (1987) Long term recruitment of softcorals (Octocorallia: Alcyonacea) on artificial substrata at Eilat (Red Sea). Mar Ecol Prog Ser 38:161-167

Benayahu Y, Weil D, Kleinman M (1990) Radiation of broadcasting and brooding patterns in coral reef alcyonaceans. In: Hoshi M, Yamashita $O$ (eds) Advances in invertebrate reproduction, Vol 5. Elsevier, New York, p 323-328

Benayahu Y, Weil D, Malik Z (1992) Entry of algal symbionts into oocytes of the coral Litophyton arboreum. Tissue Cell $24: 473-482$

Ben-David-Zaslow R, Benayahu Y (1996) Longevity, competence and energetic content in planulae of the soft coral Heteroxenia fuscescens. J Exp Mar Biol Ecol 206:55-68

Coma R, Ribes M, Zabala M, Gilli JM (1995) Reproduction and cycle of gonadal development in the Mediterranean gorgonian Paramuricea clavata. Mar Ecol Prog Ser 117: 173-183

Coon SL. Fitt WK, Bonar DB (1990) Competence and delay of metamorphosis in the Pacific oyster Crassostrea gigas. Mar Biol 106:379-387 
Crisp DJ (1974) Factors influencing the settlement of marine invertebrate larvae. In: Grant PT, Mackie AM (eds) Chemoreception in marine organisms. Academic Press, London, p 177-265

Dahan M (1992) Clonal propagation and sexual reproduction of the alcyonacean Dendronephthya hemprichi. MSc thesis, Tel-Aviv University (in Hebrew with English summary)

Farrant PA (1986) Gonad development and the planulae of the temperate Australian soft coral Capnella gaboensis Mar Biol 92:381-392

Fishelson L (1970) Littoral fauna of the Red-Sea: the population of non-Scleractinian anthozoans of the shallow waters of the Red-Sea (Eilat). Mar Biol 6:106-110

Fishelson L (1973a) Ecological and biological phenomena influencing coral species composition on the reef table at Eilat (Gulf of Aqaba, Red-Sea). Mar Biol 19:183-196

Fishelson L (1973b) Ecology of coral reefs in the Gulf of Aqaba (Red-Sea) influenced by pollution. Oecologia (Berl) 12 : $55-67$

Fitt WK, Fisher CR, Trench RK (1986) Contribution of the symbiotic dinoflagellate Symbiodinium microadriaticum to the nutrition, growth and survival of larval and juvenile tridacnid clams. Aquaculture 55:5-22

Gohar HAF (1940a) Studies on the Xeniidae of the Red-Sea, their ecology, physiology, taxonomy and phylogeny. Publ Mar Biol Stn Al Ghardaqa 2:1-117

Gohar HAF (1940b) The development of some Xeniidae (Alcyonaria). Publ Mar Biol Stn Al Ghardaqa 3:26-77

Harms J (1992) Larval development and delayed metamorphosis in the hermit crab Clibanarius erythropus (Latreille) (Crustacea, Diogenidae). J Exp Mar Biol Ecol 156: $151-160$

Harrison PL, Walldce CC (1990) Reproduction, dispersal and recruitment of scleractinaian corals. In: Dubinski $Z$ (ed) Ecosystems of the world, Vol 25: coral reefs. Elsevier, New York, p 133-207

Hartnoll RG (1975) The annual cycle of Alcyonium digitatum. Estuar Coast Mar Sci 3:71-78

Havenhand JN (1993) Egg to juvenile period, generation time, and the evolution of larval type in marine invertebrates. Mar Ecol Prog Ser 97:247-260

Jackson JBC (1986) Modes of dispersal of colonial benthic invertebrates: consequences for species' distributions and genetic structure of local populations. Bull Mar Sci 39: 588-606

Jaeckle WB (1994) Rates of energy consumption and acquisition by lecithotrophic larvae of Bugula neritina (Bryozoa: Cheilostomata). Mar Biol 119:517-523

Jaeckle WB, Manahan DT (1989) Feeding by a 'nonfeeding' larva: uptake of dissolved amino acids from seawater by lecithotrophic larvae of gastropod Haliotis rufescens. Mar Biol 103:87-94

Jaeckle WB, Manahan DT (1992) Experimental manipulations of the organic composition of seawater: implications for studies of energy budgets in marine invertebrate larvae.

Editorial responsibility: Otto Kinne (Editor), Oldendorf/Luhe, Germany
J Exp Mar Biol Ecol 156:273-284

Lasker HR, Kim K (1996) Larval development and settlement behavior of the gorgonian coral Plexaura kuna (Lasker, Kim and Coffroth). J Exp Mar Biol Ecol 207:161-175

Loya Y (1975) Possible effects of water pollution on the community structure of Red-Sea corals. Mar Biol 29:117-185

Loya Y (1986) Changes in a Red Sea coral community structure: a long-term case history study. In: Woodwell GM (ed) The earth in transition, patterns and processes of biotic impoverishment. Cambridge University Press, New York, p 369-384

Lucas MI, Walker G, Holland DL, Crisp DJ (1979) An energy budget for the Cirripedia. Mar Biol 55:221-229

Paige JA (1988) Biology, metamorphosis and postlarval development of Bursatella leachii plei Rang (Gastropoda: Opisthobranchia). Bull Mar Sci 42:65-75

Pechenik JA (1990) Delayed metamorphosis by larvae of bentic marine invertebrates: Does it occur? Is there a price to pay? Ophelia 32:63-94

Pechenik JA, Cerulli TR (1991) Influence of delayed metamorphosis on survival, growth, and reproduction of marine polychaete Capitella sp. I. J Exp Mar Biol Ecol $151: 17-27$

Pechenik JA, Hammer K, Weise C (1996) The effect of starvation on acquisition of competence and post-metamorphic performance in the marine prosobranch gastropod Crepidula fornicata (L.). J Exp Mar Biol Ecol 199:137-152

Qian PY, McEdward LR, Chia FS (1990) Effects of delayed settlement on survival, growth, and reproduction in the spionid polychaete, Polydora ligni. Invertebr Reprod Dev $18: 147-152$

Richmond RH (1987) Energetics, competency, and longdistance dispersal of planula larvae of the coral Pocillopora damicornis. Mar Biol 93:527-533

Richmond RH (1989) Competency and dispersal potential of planula larvae of a spawning versus a brooding coral. Proc 6th Int Coral Reef Symp, Townsville 2:827-831

Rinkevich B, Loya Y (1977) Harmful effects of chronic oil pollution on a Red Sea coral population. Proc 3th Int Coral Reef Symp, Miami 2:585-591

Schuhmacher $H$ (1975) The role of soft corals (Alcyonacea, Octocorallia) in the reef bioecoenoses of the Red-Sea and Australian Great Barrier Reef. Verh Dtsch Zool Ges 1974: $380 \mathrm{Abs}$

Scott JM, Marlow JA (1982) A microcalorimeter with a range of 0.1-1.0 calories. Limnol Oceanogr 27:585-590

Sebens KP (1983) Settlement and metamorphosis of a temperate soft-coral larvae (Alcyonium siderium Verrill): induction by crustose algae. Biol Bull Mar Biol Lab Woods Hole 165:286-304

Tytler EM, Spencer Davies P (1986) The budget of photosynthetically derived energy in the Anemonia sulcata (Pennant) symbiosis. J Exp Mar Biol Ecol 99:257-269

Walters LJ (1992) Field settlement locations on subtidal marine hard substrata: Is active larval exploration involved? Limnol Oceanogr 37:1101-1107

Submitted: March 24, 1997; Accepted: November 27, 1997

Proofs received from author(s): February 3, 1998 